\title{
Role of Ethiopian Economic Diplomacy in the Implementation of Integrated Housing Development Program and Real Estate Development in Addis Ababa
}

\author{
Fasikaw Eseyneh \\ School of Diplomacy \& International Relations, College of Leadership and Governance, Ethiopian Civil Service University, Addis Ababa, \\ Ethiopia
}

\section{Email address: \\ eeserael@yahoo.com}

\section{To cite this article:}

Fasikaw Eseyneh. Role of Ethiopian Economic Diplomacy in the Implementation of Integrated Housing Development Program and Real Estate Development in Addis Ababa. Science Research. Vol. 9, No. 5, 2021, pp. 89-101. doi: 10.11648/j.sr.20210905.13

Received: September 23, 2021; Accepted: October 19, 2021; Published: October 30, 2021

\begin{abstract}
This study focused on role of Ethiopian economic diplomacy in the implementation of integrated housing development program and real estate development. Besides, the paper explores the contribution of housing on the economic, political and social life of the society. Then it assessed the challenges of housing development in Addis Ababa. Thus, qualitative research method and semi structured in-depth interview was conducted. Addis Ababa is selected as a case study because the housing crisis is acute. The thesis found colossal number of houses are constructed and transferred to the society which has direct economic, political and social effect to the beneficiaries, contractures, consultants, MSE's, suppliers and others. The paper uncovers Addis Ababa housing sector had shortcomings of not utilizing technology, financial scarcity and maladministration. Moreover, Ethiopian economic diplomacy had a strategic advantage for affordable housing in getting the specified amount of materials and quality at reasonable cost directly from producers. The study concluded that the prospects and challenges of Addis Ababa housing exude from the socialist oriented government decrees, policy and procedures. Ethiopian economic diplomacy is imperative motor for housing development in Addis Ababa. The recommendation for Addis Ababa City Administration was to curb its internal maladministration problem and prepare pragmatic policies that proliferate formal housing. Finally, Ethiopian economic diplomats and joint task force shall vigorously pursuit options for housing development by breaking bureaucratic red tapes, showing gaps of housing, attraction of mega manufacturing firms, tycoon housing developers, soliciting technical and financial aid.
\end{abstract}

Keywords: Economic Diplomacy, Foreign Direct Investment, Technology Transfer, Trade

\section{Introduction}

The center of Ethiopian foreign relation is economic diplomacy that relay on the principle of "Inside Out" approach. The corner stone behind "Inside Out" approach is first use the domestic capacity and resources to our problems next fill gaps by external [1]. Ethiopian economic diplomacy (EED) lead by the principle of "Inside Out" approach have succeeded in attracting myriad of entrepreneurs as well as Foreign Direct Investment (FDI), trade and aid [2].

Housing is an indispensably component of a nation's economy. It's in reverse and forward linkages with other parts of the economy closely bond people's needs, demands and social processes with the supply of land, infrastructure, building materials, innovation, labor, and housing finance. These linkages allow housing to act as an important engine for sustainable development and poverty reduction in both society and the economy [3]. Revitalized global partnership and universal solidarity, guided by the Charter of the United Nations (UN) are crucial to meet adequate housing [4]. Sustainable development goals (SDGs) Target 11.1 "By 2030, ensure access for all adequate, safe and affordable housing and basic services and upgrade slums." It relates innovation and capacity building, domestic public resources, address systemic issues, science, technology, international trade, debt and debt sustainability, monitoring and follow up [5].

In 2005, the council of Ministers of the Federal Democratic Republic of Ethiopia formulated and approved a 
consolidated Urban Development Policy. They also created the national Ministry of Works and Urban Development (MWUD) to guide the overall development of the country's urban areas and conducting studies on its urbanization patterns [6].

Addis Ababa City Administration Housing Development Administration Office (AACAHDAO) has a mandate to follow up, monitor, supervise, lead and control, coordinates concerned bodies in the housing sector to supply affordable housing in Addis Ababa. The goal is to construct condominiums, create job opportunities, promote the development of MSE's, enhance the capacity of the construction sector, upgrading slums in cities and home ownership of low and middle income citizens [7].

Housing is multidisciplinary. The intersection of economic diplomacy and housing as well as Ethiopian economic diplomacy and Addis Ababa housing founded on construction material supply, investment in housing development projects, technology transfer, financial and technical aid. Ethiopian economic diplomacy is the artery of the country to the external world. The gaps in Addis Ababa housing development could be filled through Ethiopian economic diplomacy by the principle of "Inside Out Approach".

Interlocking of housing development and economic diplomacy yields prosperity in Addis Ababa. The Addis Ababa City Administration facilitates land, infrastructure, incentives and protection of the housing developer's investment. Addis Ababa City Administration gets construction materials manufacturing firms and direct involvement of housing development from FDI. Construction materials that are not produced in Ethiopia are imported from abroad by trade. The gaps of international experience and financial shortage alleviated through technical and financial aid. The interaction between international actors and Addis Ababa City Administration relay on the contract, international norms, national housing development and administration policies.

\section{Literature Review}

\subsection{Economic Diplomacy}

Economic diplomacy targets the inefficient aspects that prevent international trade and FDI. The point of economic diplomacy is to impact choices on cross-border financial activities [8]. Economic diplomacy is characterized as follows:

Trade and investment promotion: - This incorporates the advancement of exports as well as imports. It moreover incorporates the advancement of cross border investments. This includes data gathering and providing, country branding and admonitory tasks [9];

Securing property rights and the stability of economic relations:- This includes arranging bilateral investment treaties and respective trade agreements. It aims at reinforcing the benefits of favorable political relations in this manner reducing the risk of international flows [10];

Impacting foreign national policy making in favor of domestic multinational ventures These exercises include the use of bilateral contacts aimed at handling particular barriers that obstruct the commercial interest of internationally active household companies [9];

Keep up a favorable international policy environment: This includes the governments' multilateral efforts to protect a functioning global governance system for trade and financial flows [10].

\subsection{Ethiopian Economic Diplomacy}

Ethiopian foreign and national security policy ought to have the mission of securing national interest and security. By national interest it refers to the interest of the whole people - no more, no less. Our national interest is all around democracy and development. Moreover our foreign and national security arrangements based on, and cause the advancement of, development and democracy. The strategy is economy-centered strategy based on the "domestic first, external second" approach. The thought is to focus on what can be done by us, and to meet require of our domestic necessities. We ourselves ought to choose what to do, how to do it and when to advance democratization and development, as foreign prescriptions cannot lead us to effective results. We moreover mean that our outside action ought to center on promoting business and investment opportunities and distinguishing sources of aid and credit. It implies guaranteeing that Foreign Service officers realize that they are first of all development officers [1].

The primary interest of the people is to live free from poverty, disease and ignorance. Quick development isn't simply vital in raising the standard of living of the people, but too a guarantee of national survival. In this manner, guaranteeing quickened advancement and raising the living standard of our individuals is basic in anticipating our nation from disaster and dismemberment. This is an essential issue on which the interests and the survival of the individuals of Ethiopia depend [11].

\section{A. FDI}

The investment openings in Ethiopia since the economic growth will be driven by principal and the "Inside Out approach". In 2010, Ethiopia propelled it's to begin with Growth and Transformation Plan (GTP I), and, in 2015, the moment arrange (GTP II) mechanical parks are 'necessary' to reach 'Ethiopia's objective of getting to be Africa's light fabricating hub' (Ethiopian National Planning Commission, 2016). Ethiopia points to become a low middle-income nation by 2025, and the government envisions the foundation of roughly twenty Special Economic Zones (SEZs) all through the nation, both state and privately owned [2].

The high-level Chinese support for investment promotion through the establishment of SEZs across Africa has been reiterated at the Ministerial Conferences of the Forum on China-Africa Cooperation (FOCAC) since its creation in 2000. At the third FOCAC Ministerial Conference in 2006, former Chinese President $\mathrm{Hu}$ Jintao declared that China 
would establish between three and five SEZs in Africa, out of which one, the privately run Eastern Industrial Zone, was established in Ethiopia in 2007. The establishment of the government-run Bole Lemi Industrial Zone followed in 2012, co-financed by the World Bank. In 2016, the Hawassa industrial park was inaugurated, and in 2017, the Kombolcha and Mekelle industrial parks were inaugurated while another six SEZs are under construction. The China Civil Engineering Construction Corporation (CCECC) serves as the main contractor for the construction of the industrial parks [2]. So far, textile, garment and shoe manufacturers from China, Turkey and several other countries have established production in Ethiopian SEZs. Retail chains such as Tesco, Walmart and H\&M have begun sourcing their goods from Ethiopia [12].

\section{B. Trade}

Ethiopia has made a number of preferential trade agreements with many countries. Under the various Generalized System of Preference (GSP) schemes, Ethiopia is one of the beneficiaries of preferential trade access for a wide spectrum of commodities from a number of developed countries, including, among others, Australia, Canada, the European Union (EU), Japan, Norway, and the United States of America (USA). The two most important duty free market access opportunities that Ethiopia currently enjoys are the Everything But Arms (EBA) and Africa Growth and Opportunity Act (AGOA) schemes. Moreover, Ethiopia is currently negotiating to join the multilateral trading system. Ethiopia has the opportunity to and the challenge of coming up with a consistent negotiating agenda with respect to economic partnership agreement (EPA) [13].

Ethiopia's trade balance has always been heavily in the negative. What is more the structure of both exports and imports are highly skewed to EU. The EU is Ethiopia's favorable export market. Accordingly, for over half a decade on average, over one third of the total export was destined to this market, followed by Asia (18 percent) and the Middle East (16 percent). But considering the dynamics, the shares of Asia and the Middle East are fast increasing at the expense of the EU [13].

\section{Aid}

When the IHDP began, the German Technical Corporation (GTZ) provided start-up assistance. The GTZ Low-Cost Housing Project was instrumental, assisting in the design and implementation of elements involved in low-cost construction. In 2010, GTZ handed over its responsibilities in the program to the Housing Development Project Office [3].

The project recorded some impressive gains over the first decade and a half of its implementation. For example, although the target of 400,000 new housing units was not reached, by 2015 , the program was able to build 245,000 units. Moreover, 370,000 new job opportunities were created, well surpassing the original goal of 200,000 [7].

\subsection{Housing Conceptual Framework}

The concept of 'home' is not amenable to an objective definition, and even definition of a 'house' is difficult to formulate. Housing protects and provides vital human needs. Secure safe housing shields us from the elements and provides refuge from external threats. It gives us a material base to build livelihood and take part in the community and state. In addition it provides us a space in which our psychological needs can be met. Those whose housing is inadequate, who are forced from their homes, and who are homeless suffer severe personal and social deprivation with both psychological and material impacts [14].

\subsubsection{Models of Housing}

There are different models (views) of housing. This view emanates from the orientation of the government like socialist, capitalist and the current pragmatic ones. Models of housing are discussed below.

Social housing means building and maintaining housing in the public interest and insulating it from market forces that incentivize speculation. A major commitment to social housing is a long-term goal that requires a re-definition of the public sector's role in housing provision and stewardship (Backyard, February 21, 2020). Common features of social housing can be summarized in to two. The first State dominated the production, consumption and allocation of housing. It means functioning of the market was restricted and kept subordinate. Secondly, housing was understood mainly as a social right, serving to meet housing needs, and not as a commodity. In other words, it was the shelter function, not the investment (property) function [15].

The socialistic approach of housing did not result in the desired goal of "housing for all." To implement a new market-based housing system laws and regulations to permit transferring, leasing, and mortgaging private rights to property, including housing. Housing affordability is essential to sustainable economic development and political stability in every country. The sums of all government produced low cost houses are not sufficient to the demand. The government shall provide incentives to real estate developers to build low cost houses besides luxury apartments [16].

The neoclassical approach considers housing mainly as a commodity. Neoclassical economics is a broad theory that focuses on supply and demand as the driving forces behind the production, pricing, and consumption of goods and services [17].

Housing deviates from the neo-classical assumptions mean that some features of this model may not be present in a housing market. For example, supply may be inelastic in that it is slow to respond to changes in demand, a feature that has been shown in many different national housing markets. This means that markets may not 'clear' in the neoclassical sense with markets able to stay in disequilibrium for long periods of time. Disequilibrium may mean long term problems of housing shortage or unaffordability that the market itself cannot correct in the way that neo-classical theory would predict, thus opening the door for state intervention [18].

Distributive justice theory is application of justice in housing. The economic, political, and social frameworks that 
each society has - its laws, institutions, policies, etc.- - result in different distributions of benefits and burdens across members of the society. It is difficult to achieve a high level of justice via comprehensive state-run housing policies. This should not be surprising, given the complexity of the task. But it has proven to be an equally ambitious task to leave fairness to the private market system, at least with respect to housing for the poor. Justice in housing markets is perhaps the toughest theory to apply [19].

The application of disciplinary theory, whether from any of the mainstream disciplines, is likely to be problematic. The complexity of housing has meant that it has been examined through the lens of different disciplines, each of which has offered important insights. Bringing these together into a coherent single theory is extremely desirable, but it is probably not possible to achieve at present. The unique characters of housing, unlike most consumer goods, are it is expensive, housing is long lasting and so most households only transact in the market a small number of times [18].

\subsubsection{International Conventions About the Right to Housing}

Housing is explicitly included as an aspect of the right to an adequate standard of living. Article 25(1) of the Universal Declaration of Human Rights (UDHR).

Everyone has the right to a standard of living adequate for the health and well-being of himself and his family, including food, clothing, and housing and medical care and necessary social services, and the right to security in the event of unemployment, sickness, disability, widowhood, old age or other lack of livelihood in circumstances beyond his control.

The clearest international expression of the right to housing is Article 11(1) of the International Covenant on Economic, Social, and Cultural Rights (ICESCR).

The States Parties to the present Covenant recognize the right of everyone to an adequate standard of living for himself and his family, including adequate food, clothing and housing, and to the continuous improvement of living conditions. The States Parties will take appropriate steps to ensure the realization of this right, recognizing to this effect the essential importance of international cooperation based on free consent.

As codified in or implied in to international and regional rights treaties and declarations the right to housing is human rights. Housing rights, on the other hand, refer to legal rights codified in to or arising from the domestic law of particular national states. This refers to economic, social and cultural rights [14].

The right to adequate housing contains freedoms. These opportunities incorporate: assurance against forced evictions and the subjective destruction and demolition of one's home. The second right is to be free from arbitrary impedances with one's domestic, protection and family. Assist the proper to select one's home, to decide where to live and opportunity of development [20].

\subsubsection{Misconception of the Right to Housing}

The right to adequate housing does NOT require the State to construct housing for the whole population. One of the foremost common misguided judgments related with the proper to satisfactory housing is that it requires the State to construct housing for the whole populace, which individuals without housing can consequently request a house from the Government [21].

The right to adequate housing isn't only a programmatic objective to be achieved within the long term. Another misconception is that the right to adequate housing does not force quick commitments on the State. On the opposite, States must make each conceivable exertion, inside their accessible assets, to realize the right to adequate housing and to take steps in that course without delay. Regardless asset limitations, a few commitments have immediate impact, such as the undertaking to ensure the right to adequate housing in an equal and non-discriminatory way, to create particular legislation and plans of activity, to avoid forced evictions or to ensure a certain degree of security of tenure to all [21].

The right to adequate housing is NOT the same as the right to land Access to land. As such, the enjoyment of the right to adequate housing might require, in certain cases, securing access to and control over land. Nevertheless, international human rights law does not, currently, recognize a selfstanding right to land [21].

The rights to adequate housing does NOT obscure development projects which seem displace individuals. There are inescapable needs for the redevelopment of certain parts in developing cities and for public offices to get land for public utilize and infrastructure. The right to adequate housing does not avoid such improvement from taking place, but forces conditions and procedural limits on it [21].

The right to adequate housing incorporates guaranteeing access to adequate services. There must too be economical and non-discriminatory get to offices basic for wellbeing, security, comfort and sustenance. For illustration, there must be get to secure drinking water, vitality for cooking, warming, lighting, sanitation and washing offices, and implies of storing food, deny disposal, site waste and emergency services [21].

\subsection{Economic, Social and Political Contribution of Housing}

Politicians in numerous nations, and from over the political spectrum, routinely talk about housing in terms of a 'crisis': require for pressing policy mediation. This emergency has an including topography, influencing both the Worldwide North and South, and it is all as well common to examined about housing emergencies in the scale of the concern is additionally not kept to bigger cities, as regional centers and littler urban regions have too continuously ended up portion of the talk [22].

Housing is a driver of economic development. For developed economies (countries) macroeconomic impacts of housing account for a critical parcel of yearly GDP, Housing generates expenditures outside the housing 
segment. In addition housing and real estate asset classification leads to more prominent market effectiveness, steadiness, and liquidity. In developing economies (countries) housing development has different advantages. The first it may be a stimulus to creation of little businesses. Moreover microfinance for housing which will be bundled with loans for business improvement [23].

On the social side, housing is, after food and medical care, the primary need of defenseless populations following normal and man-made catastrophes. In better times, great housing builds riches by increasing in value in esteem, giving a fence against inflation, giving secure premises for income-generating exercises, and opening the entryway to credit. Incremental investment in housing permits poor families to move forward their wealth base over time, as assets ended up accessible. And clean, warm housing is a fundamental input for prevention and care of infections of poverty like HIV/ AIDS, tuberculosis, diarrhea, and malaria [24].

\subsection{Conceptual Framework of the Study}

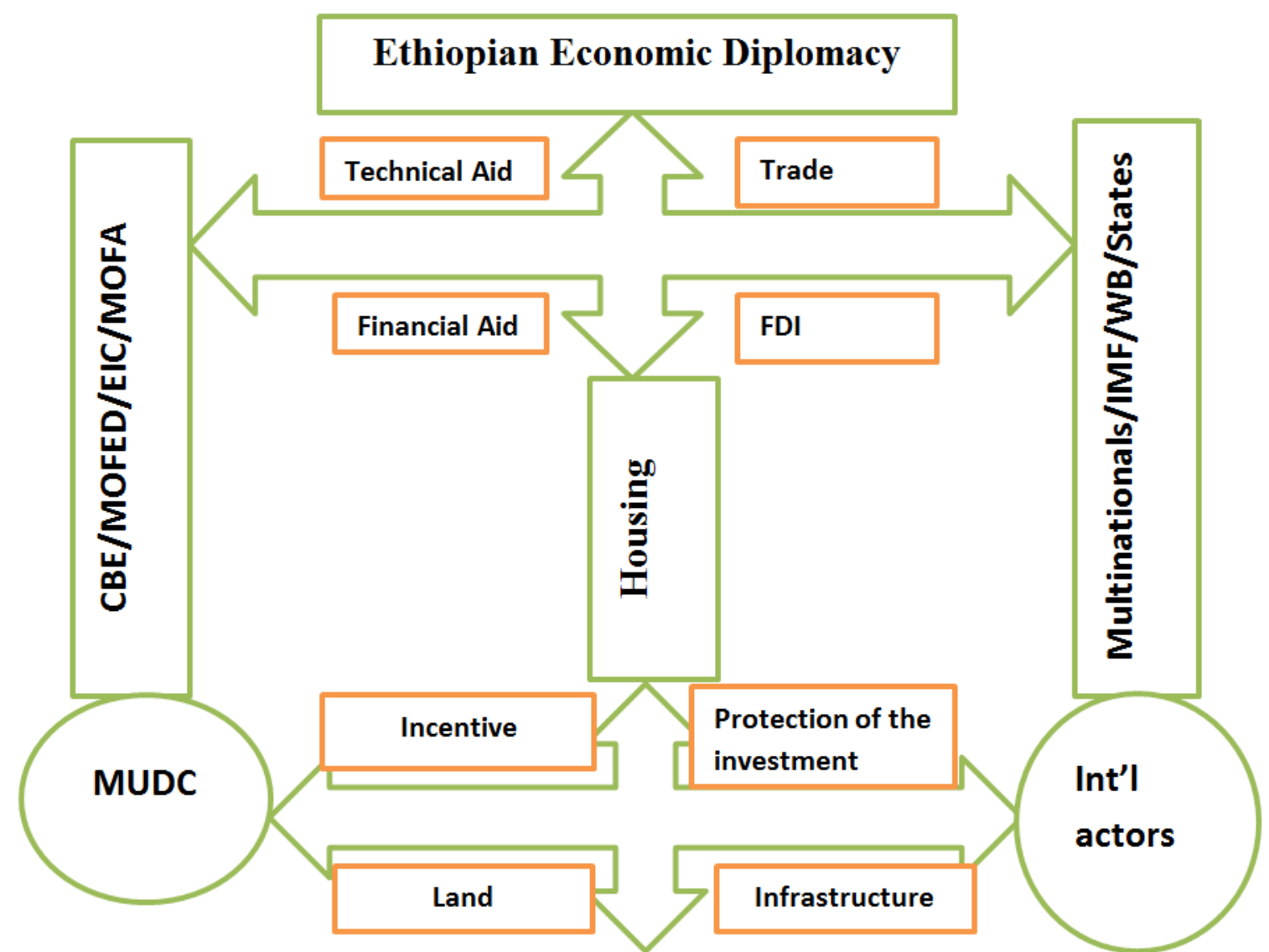

\section{Addis Ababa Integrated Housing Development Program and Real Estate Development Designed by the Researcher}

Figure 1. Interlocking Ethiopian Economic Diplomacy and Addis Ababa Housing Development.

Interlocking of housing development and economic diplomacy yields prosperity in Addis Ababa. Addis Ababa City Administration facilitates land, infrastructure, incentives and protection of the housing developer's investment. Addis Ababa City Administration gets construction materials manufacturing firms and direct involvement of housing development from FDI. Construction materials that are not produced in Ethiopia are imported from abroad by trade. The gaps of international experience and financial shortage alleviated through technical and financial aid. The interaction between international actors and Addis Ababa City Administration relay on the contract, international norms, national housing development and administration policies.

\section{Research Methodology}

The decision for methods of the research stems from the nature of issues studied. This research is conducted on qualitative method as it mainly focused and tries to understand the role of Ethiopian economic diplomacy in the provision of adequate housing. Besides, it tries to explore the challenges of housing supply in Addis Ababa and how Ethiopian economic diplomacy fills the pitfalls. Further the spillover effect of housing on the economy, social and politics as well as the creation of wealth on the society are shown. 
The researcher used judgmental or purposive sampling for in-depth interview. The directors of government officials and senior expertise in the housing construction, real estate development and other are selected. Six samples are selected based on purposive sampling.

Besides, convenience sampling employed for selecting the households registered in 20/80 and 40/60. Samples are selected from the population only because they are conveniently available to the researcher. Ten samples are selected by convenience sampling method.

The last one is uncontrolled observation of Tsehaye real estate compact city, Meri loki and Hintsa akerabi sites contract document and the progress.

As the study employed a qualitative research method, the gathered information is analyzed based on the qualitative method. Analysis of this research conducted in the process of data collection to identify the information gaps and information needed in adequately dealing with the research questions.

As this research relied on multiple sources, the information collected were organized and categorized based on their type and the question they responded in a way, spillover effects of housing in the economy, social and political life, gaps of in the implementation of integrated housing development program and role of FDI, trade and aid for housing development. The role played by Ethiopian economic diplomacy can be understood how it fills the gaps by "Inside Out Approach".

\section{The Role of Ethiopian Economic Diplomacy for Housing Supply in Addis Ababa}

The significance of Ethiopian economic diplomacy in the housing sector presented through FDI, trade and aid.

\section{A) FDI}

According to a team leader in Ethiopian Investment Commission (EIC),

EIC opens investment licenses for the construction Grade one general, road, building, water or special construction for foreign investors. Besides real estate development is also given to foreign investors. Further construction materials manufacturing like cement, rebar, ceramic and others investment licenses are open to the foreign investors.

EIC is mandated to facilitate the allocation of land for FDI projects throughout the country. The lease and rental prices of urban and rural land vary according to location, type of investment and class of land. Land cannot be sold or mortgaged, but the rent or rental value of land and the settled assets consequently may be sold or exchanged to a third party.

Ethiopia is a member of a lot of international organizations such as Multilateral Investment Guarantee Agency, a World Bank affiliate and a signatory to the Convention on the Settlement of investment disputes among States and Nationals of other States.
EIC allowed foreign investors the right to make the listed remittances out of Ethiopia in foreign currency: dividends and profits, principals and interest payments on external loans, technology transfer based payments, payment made for compensation of investor and income from the sale or liquidation of an enterprise, transfer of shares or partial ownership of an enterprise to a domestic investor.

As Abebe Abebayehu (Commissioner, EIC) speech to CGTN," FDI quadrupled in Ethiopia over the last five years. Ethiopia has positioned itself as strategic location of choice for FDI. The Chinese base companies are the forerunners."

One of the team leaders in EIC said,

The attraction of foreign companies in construction sector builds the human capital by training. This has spillover effect of constructing on time and quality. It is possible to say foreign construction companies have changed the culture of the construction. It enabled our capacities in the building of mega projects.

Further number of foreign investors registered in the real estate sector is enormous. But their significance is nearly negligible currently limited to Tsehaye Real Estate and Metropolitan Real Estate. Nearly all real estate developers ask for incentives from the government to build affordable.

Chinese real estate developer has built a city with in a city in CMC, Addis Ababa. It is an investment project that targets the rich. As Mr. Tenaadam Zewudie has made speech on EBS TV [25].

Tsehaye real estate is compact city complex. The design of the city complex was done 15 times before the construction. The designers did in detail about concept design, necessary facilities and others before starting the construction.

After that the construction started in 2013. The structural construction, infrastructure and greenery were done in parallel way. The structural construction took 8 months for 13 blocks $B+G+12$. The project used batching plants for concrete casting.

Each day the strength and weakness of the project is analyzed. Day and night were working times. The team works in coordination and discipline. It is the international experience. It is possible to say the first in most African countries in the usage of urban land effectively. The housing developers share technical and administrative knowledge for Ethiopians.

I visited housing development projects that are built by foreign investors and Ethiopian Government. Tsehay real estate, Meri loki and Hintsa Akerabi sites. The project of AAIHDP in Meri Loki and Hintsa Akerabi sites lags more than threefold because.

1) Design of Meri Loki and Hintsa Akerabi site is not fully finished before the construction. Because of technical and administrative problem.

2) The structural construction and infrastructure works aren't done parallel. The causes are technical and administrative problem.

3) There is no work in the night. The main causes are administrative and financial problem.

4) The coordination of contractors, aluminum, electrical 
MSE'S, sanitary MSE'S and others are very poor. Correction works are recurrent this leads to additional cost for demolition and construction.

Even though Tsehaye real estate finishes the construction before three years, the houses are not fully transferred. The cost is more than threefold when you compared to AAIHDP built houses like Meri Loki and Hintsa Akerabi sites.

It is unaffordable because:

1) The areas of the houses are very vast;

2) It is luxury apartment;

3) Government facilitates little or no incentives and

4) Profit oriented project.

As Ambassador Shamebo Fitamo, MoFA Middle East Affairs Director General, interview with Ethiopian Herald [26] stated that the renewed approach to economic diplomacy has given utmost priority to capitalize on the Gulf State's enormous capital in a view to ensuring economic progress and curbing extreme poverty and unemployment. A big UAE-based company, namely Eagle Hills, invested two billion USD in La Gare's real estate project for residential and business purposes, many other Gulfs flagship corporates are coming here with huge financial and technological calibers, and he pointed out.

As Ms. Tewabech H. Molla, Head of Dubai Chamber International Office, Ethiopia, interview to MOFA Business Diplomacy Update [27],

I have been with Dubai Chamber since August 1, 2018. I can tell you that since I started, we have re-launched our office and have been actively promoting bilateral trade. We have created a means for investors to have a streamlined process so that they can make investment decisions quicker and start their projects faster. There are a few projects in the pipeline that I am happy to say it will be implemented in the near feature.

We work closely with the EIC and other key stakeholders to keep up to date on current investment opportunities as well as follow current changes to investment policies, rules and guide-lines. One of the most important things that we do is we constantly communicate up to date information to our contacts. We also focus on the investment incentives in targeted sectors for UAE investors and ensure that potential investors get the most current information available.

Recently we had a roundtable discussion with key stakeholders to identify current priority sectors and incentives. We are now working to create a campaign to promote these priority sectors and incentive schemes for $U A E$ Investors to attract them to invest in Ethiopia.

Housing (real estate) development gets attention by higher officials and international investors.

Adanech Abiebie (Deputy Mayor of Addis Ababa) signed a contract agreement for the construction of 30,000 houses with Wadi housing developer in May, 2021. The UAE government supports the project. The Addis Ababa City Administration prepared land [28].

The Deputy Mayor of Addis Ababa Adanech Abiebie signed a contract agreement for the construction of 100,000 houses with Property 2000 South African Company. The company invested 4.2 Billion Dollar that can be paid in $30 \mathrm{yrs}$. with $1 \%$ interest. $90 \%$ of jobs will be created for the local people. The Addis Ababa City Administration prepared land and tax exemptions for imported construction materials [29].

Ethiopia's foreign policy, in fact, maintains that economic diplomacy is an instrument of rapid economic growth, pivotal to build the capacity to withstand internal and external threats. Economic diplomacy, therefore, implies the removal of domestic and international handicaps to rapid development using diplomatic instruments such as representation, protection, communication, negotiations and political pressure. Central to this is the importance of juxtaposing the rhetoric of policy with the praxis, the practical application, reviewing the performance of economic diplomacy in creating conducive international environment for economic development [11].

One of the officials in EIC said that Ethiopian government followed the import substitution of most construction materials. Domestic and foreign investors are involved in import substitution. The companies started manufacturing like cement, rebar, sanitary and electrical materials. The vast market in Ethiopia attracts foreign investors. Ethiopia's cement and other industry have enjoyed substantial growth in the past decade. So, Ethiopian markets especially in cement were stable for long time.

One of the contractors in AAIHDP said,

Before 15 years most of the construction materials comes from foreign countries.

Currently enormous construction materials are produced in Ethiopia. The materials include ceramic, cement, quartz, EGA and others. This allows us to get a better quality, to the required quantity and fair price construction materials. That means the cost of transportation and other issues are reduced. So, directly or indirectly it has a great role in the housing projects.

Over 17 companies are engaged in Ethiopia's cement market. Dangote Cement's Dangote Industry Ethiopia holding the lion's share after the Nigerian-based company commissioned a 2.5 million-ton plant in 2015. The plant, 90km from Ethiopia's capital Addis Ababa, is the largest and most modern cement plant in Ethiopia, producing 32.5 and 42.5-grade cements, according to the company's latest annual report [30].

Derba Midroc Cement PLC. (DMC) invested a total cost of USD\$ 600 million, the company is one of the largest and stateof-the-art cement factories in Ethiopia. This includes Derba Cement, Derba Transport with over 800 Volvo trucks and Maya PP Bag. The cement plant is located at the top of Muger valley - some $70 \mathrm{kms}$ North-West of Addis Ababa [31].

Ethio Cement has been incorporated as a joint venture between an Ethiopian investor and WACEM (West African Cement SA) a company promoted by Indian entrepreneurs, having the base at Togo, West Africa. The plant is located near Addis Ababa, capital of Ethiopia, where the $75 \%$ of cement is consumed in the country. The project cost of about birr 1700 Mln is financed by equity capital Birr 1000 Million and balance by way of term loans from Development bank of [32]. 
According to one of the director in AAIHDP the attraction of foreign investors' in the manufacturing of construction materials are very critical for the construction of affordable housing. For example Dangote planted the biggest cement factory in Ethiopia. Aftermath of Dangote, the cost of cement reduced from 500 and above to less than 250. This is very clear and easy way of showing the impact of FDI in the supply of affordable housing.

One of the directors in AAIHDP said: "Construction materials manufacturer and housing construction projects relation is win-win. For example cement manufacturers directly supply in bulk for the housing projects. The housing projects benefited in quantity, quality and cost. The cost of cement reduced from 500 and above to less than 250 this has a great impact to the supply of affordable housing. They get opportunity of bulk sales in hundred millions.

One of the officials in EIC in the construction sector mega construction material producers mainly asks for electric power and foreign currency. Currently the demand and supply of construction materials are not balanced specifically on cement. So the government invited additional two cement producing companies. Cement producing companies get priorities for the foreign currency.

Melaka Alebel, Minister of Trade and Industry, attributed the root cause of the supply shortage to shortcomings in the cement industry, such as a lack of spare parts, power outages, lack of inputs including raw materials, security issues and a lack of leadership and professional skills. In the past, foreign currency availability has also been an issue for companies seeking to source space parts from overseas. Truck shortages have also hindered the delivery of cement [33].

There is lack of coordination among stakeholders, a shortage of competent and intuitive diplomats and professionals, and an over-stringent bureaucracy as well as the danger of saturation, land leases politically contentious, increasing tension between political and economic priorities or even the recent political unrest remains constraints that the government must work out [11].

B) Trade

According to one of the directors in AAIHDP, before 2018 most of the construction materials were bought by international bid. Federal procurement and asset removal authority announce, procure and sign a contract for supply of construction materials. AAIHDP administer the contact signed by Federal procurement and asset removal authority.

The strategic materials like rebar imported from China, Ukraine and Turkey. There are great benefits for the supply of construction materials discount with cost, sufficient quantity and required quality. Besides the government allowed tax free construction material supply for affordable housing projects. For example rebar were bought from 9 up to 18 birr per $\mathrm{k.g}$ currently in Ethiopian market $1 \mathrm{k.g}$ of rebar is around 50 birr which is triple to the cost of international bid.

On the other side one director of AAIHDP said,

The government entered in to non-strategic construction material supply. The process has a problem of foreign currency, delay and transport problem in Djibouti which lead to additional demurrage payments. In addition there are also problems how to handle those materials at stoke and site level. Further the project time elapsed triple times because of shortage of materials and coordination problems among stake holders.

After 2018 we have entered supply and fix contract that means the contractor is responsible for the entire project. The contractor plan which material shall be available for what he will do. AAIHDP controls the progress, quality and time.

AAIHDP couldn't manage a lot of stakeholders to adders the burning issue. In addition the internal problems related to capacity problems and others the project couldn't move forward. So decentralizing the powers from AAIHDP to a lot of contractors, suppliers and others could provide the expected goals.

One of the directors in AAIHDP responded that we don't have any differences about the problems. The solution isn't taking responsibility from the government to the incapable contractures. $1 \mathrm{k} . \mathrm{g}$ of rebar is around 50 birr which increases three folds. The incremental cost is added to affordable housing program. This leads the program unaffordable.

The AAIHDP shall identify strategic construction materials which has major quality, cost and quantity problems. So the strategic materials shall be supplied by the international bid. If the material isn't produced in Ethiopia the issue of foreign currency still not solved. The supply of construction materials from abroad by international bid allow affordable housing.

As Qian Xiao, Owner of Tsehay Real Estate, "The biggest challenge is importation. In Ethiopia there is no enough industry system to different construction materials. So, most construction materials are imported from abroad [34]."

As Eng. Tsedeqe Yihuni, founder of Flint stone homes, "Housing provision becomes difficult for us due to sequence of shortage of material, foreign currency problem for importing finishing materials [35]".

As one of the managers of Metropolitan Real Estate "Nearly $99 \%$ of our finishing materials come from Turkey and Europe [36]."

According to one of directors in AAIHDP, "International actors contribute to the supply of construction materials like rebar, sanitary, electric and finishing materials with international bid. The supply of construction materials international bid abroad takes the lion share of housing projects."

C) Aid

One of the senior officials in MUDC said that the relation between MOFA and MUDC is very weak. Housing needs cooperation including attraction of financial and technical aid. The cooperation shall be tight to meet the housing demand. Ethiopian diplomats and ambassador shall work closely to technology transfer like preparing exposure visit. We can copy international experience in cooperation with MOFA. International housing developers shall be invited from MOFA based on their relation platform."

According to the data given by UN representative in MOFED Ms. Hanna, Ethiopia gets technical assistance grant 
and loans from UN group, international financial institutions, European Union and bilateral relations. Some of the aid is given to urban development Addis Ababa, capacity building, social development and others. The bilateral relation with Germany provides GTZ technical assistance to low cost housing at the beginning of the low cost housing in Addis Ababa. The reason for the withdrawal of GTZ from technical assistance of low cost housing is not clear.

On the other hand one of the higher officials in MUDC said,

There is backdrop of technical aid in AAIHDP. When GTZ worked in cooperation with AAIHDP the projects were going on time with little deviations. After the withdrawal of GTZ around 2012/13 the housing projects time frame elapsed more than triple folds from. Technical aids related to engineering know how and technology transfer is very critical in AAIHDP.

AAIHDP mimicked agro stone technology from China. Technology transfer with regard to agro stone shall be expanded. The main advantage of agro stone is saving time, energy and cost in the construction of partition work. It can be called as the best practice. The advantage of technology transfer is modernizing the housing development and providing adequate home with the given time.

International NGOs have also been engaged in upgrading urban houses and provision of facilities and services. NGOs like Concern, Oxfam and Norwegian Save the Children Fund have been involved in upgrading of slum areas and were working together with communities in poverty mitigation efforts in both rural and urban centers in Ethiopia [37].

According to the senior official in MUDC, "International actors are working for poverty alleviation and sustainable development. GTZ, UN Habitat and World Bank have been financing problem solving research for housing. UN Habitat, GTZ and World Bank works closely with MUDC research works. These have to be transferred to technical and financial support for the provision of adequate and affordable housing.

GTZ, UN Habitat and World Bank direct involvement has multiplier effect to the provision of affordable housing. It enables technology transfer, financial support and technical assistance.

\subsection{Economic, Social and Political Contribution of Housing in Addis Ababa}

The ambitious plan of Ethiopian government home ownership for the low and middle income citizens in extended period of credit gets the heart and mind of enrolled family units and numerous others. Housing is the imperative motor for sustainable development and poverty reduction work. On its implementation the fulfillment of the program to enrolled family units is diverse. Most of family units are not satisfied since they couldn't get their home based on the agreements. The success and failures of the government is related to its policies, proclamation and bureaucracy of the government. The home ownership is more of capitalist idea. The construction of housing is mainly dominated by the government which is socialist concept. Besides, the government couldn't facilitate infrastructure, land, finance and other related issues for housing development.

The social effect of housing is exceptionally incredible. Socially home ownership creates stability and psychological advantages. It is a primary need after food and medical care. Habitable homes make a sense of socially respected and psychological benefits. Inhabitants have improved physical environment from slums, unsecured security of tenure and homelessness. Habitable home is a fundamental input for prevention and care of illnesses.

Integrated housing development program and real estate development in Addis Ababa have a multiplier impact on the economy. Housing has a direct spillover effect to the MSE's, construction materials suppliers, contractures, consultants, real estate developers and others. Housing development is the major and biggest job creation center in Addis Ababa City Administration.

Politically housing is a bone of contention between political parties. That means it has effects to the grievances and support of the government. Politically housing development needs strong political will, commitment and investment. Any political party who can adders the housing crisis in Addis Ababa can get the heart and election card of the society. Besides colossal numbers of work openings encourage youth and diminish unemployment. After the transfer of houses the society organized themselves and low level organization takes place.

\subsection{Factors Obstructing IHDP and Real Estate Development in Addis Ababa}

The main challenge of integrated housing development and real estate development in Addis Ababa emanates from the socialist oriented government decrees, policy and procedures that entitled the government as a major actor. The State dominated the production, consumption and allocation of housing. It doesn't result housing for all. On the other hand, housing shall not be considered as a commodity or investment mainly. The right to housing is human rights. Housing rights are economic, social and cultural rights. So, the bounded interference of the government is important because there are market disequilibrium and failure of private sector to supply housing for the poor, medium and high income citizens. As Mr. Samuael Tafese, President of Sunshine Investment group,

Most of the time the government couldn't have a chance to construct homes to the required quantity in a specified time. The role of the government shall be changed from main actor to planning, monitoring and controlling. So the private sector shall help based on the need of the society. The international experiences show us the private sector is the main actor in the provision of adequate housing [35].

Housing development firms are not fruitful in meeting the demand. They don't utilize high construction technology that meets the request of mass housing. Other than there are no enough construction materials fabricating industries in Ethiopia. This leads the housing provision troublesome due to a series of imported materials with lack of foreign 
currency. It is exceptionally clear the construction material supply is indebted with negative trade balance. As Dr. Meskerem Zewudie, Head of AACAHDAO, "we don't utilize technology on the housing development. In addition financial options are not used/ seen very well [29]."

The government utilized housing as a stick and carrot. Before 2018 supporters of the party get employments and houses. After 2018 the new administration pioneers are changed regularly. Most of the leaders take houses built for low and middle income citizens. The new administration claimed the distribution of houses as a distributive justice for disadvantaged farmers. The housing provision, administration and development are not reasonable, transparent and responsible which is the manifestation of socialist theory of housing.

Integrated housing development and real estate development in Addis Ababa confronted basic financial issue. The government policies didn't attract and protect foreign housing developers. The current financial approach of housing development is unsustainable. Besides, there's an intense deficiency of foreign cash for the supply of construction materials. Housing has a least priority in CBE with regard to getting foreign currency. As Mr. Tadesse Kebebe, Manager of Housing Development and Administration in MUDC, "Housing development program has a critical scarcity of finance and technology. We shall see other options. The government only couldn't solve the problems. To address the housing problem the private investors and government shall work cooperatively [35].”

Commercial Bank of Ethiopia facilitates credits for 10/90, $20 / 80$ and 40/60 schemes. The loan is partitioned in to two construction bond and the beneficiaries' of schemes. Besides based on the memorandum of understanding the bank gives mortgage for Embassies, NGO's and international organizations if they save at least 500,000 USA dollars annually. The bank doesn't have a direct mortgage for private real estate developers. Besides, CBE didn't give priority for housing development. Housing development needs secured financial sources both on the supply and demand side of the housing chain. So, to alleviate this challenge to cherished values National Housing Mortgage Bank is critical.

Private real estate developers construct houses for diplomats and tycoon Ethiopians. The private real estate developers focus on presale to adders the challenge of finance. It is not affordable for all income levels. The government couldn't facilitate the easy of accesses to infrastructure land, mortgage loans and incentives for the private sector. The private sector focuses on presale. In addition some private developers have a problem of security of tenure. The number of houses built in the private sector is less than $1 \%$ (non-existent) when it is compared to the government.

The construction industry and the nation in general lag behind in terms of technological development. However, the improvement of the capacity and performance of the industry to international competitiveness cannot be achieved through use of obsolete or inappropriate technologies and practices.
Thus, to meaningfully improve the competitiveness of the industry, vigorous pursuit for technological development is needed. The strategic application of information technology that's progressively getting to be cheaper, more effective and more effortlessly accessible requires too aggressive advancement [38].

Moreover, world-wide, there are famous research and advancement institutions which act as gatherings for exchange of knowledge. In any case, Ethiopia does not successfully take an interest in most of these forums. In this way, it loses opportunities for capturing best experiences much required for technological change. Over a long time, there has too been an unfortunate neglect of good traditional materials and technologies. However, attainment of the nation's development goal requires the optimal use of traditional or local materials and technologies [38].

\subsection{The Role Ethiopian Economic Diplomacy for Housing Supply in Addis Ababa}

The Chinese base companies are forerunners in Ethiopia FDI. Foreign construction companies have changed the culture of construction in Addis Ababa. They capacitate the local human capital by training. It has impact on the culture of development in Ethiopia on time and quality wise. Our capacities of building mega projects are increasing.

Foreign companies, joint ventures and local investors enlisted for housing development is colossal. Their significance in creating houses is insignificant and unaffordable to the society. Because:

1) There are no incentives related to construction materials,

2) Lack of serviced land supply by the government,

3) Under developed financial system that is manifested by lack of mortgage bank.

The relation between housing development and construction materials manufacturing firms are win-win. Ethiopian government pulls in bunch of construction materials fabricating firms based on the import substitution principles. It is productive in cement, gypsum, paints, and a few sanitary and electrical materials. However the firms couldn't fulfill the local request and begin export. Till presently most finishing materials and others are imported from overseas. This is the cause of intense deficiency of foreign currency. So, the government shall attract foreign construction materials manufacturing firms by creating favorable environment for investors.

Before 2018 most of the construction materials were bought by international bid by AAIHDP. It has advantage of getting the specified amount and quality at reasonable cost directly from producers in China, India, Turkey, Ukraine and others. Besides there are government incentives tax free. This makes affordable housing applicable with its challenges. Post 2018 the material supply is transferred to each contractor. So, the importation takes place the other means. This has advantage of lessening the load in AAIHDP. The cost of material delivery increases due to lack of incentives and profits in a series of steps from manufacturer. The costs have 
a direct impact on the provision of affordable housing. In both cases the deficiency of material and foreign currency is a major challenge.

Post 2018 tycoon housing developers and government begin to work cooperatively to address the crisis of housing in Addis Ababa. The Addis Ababa City Administration opened the entryway for foreign housing developers and signed a series of memorandum of understanding and agreements. International cooperation is basic to illuminate the housing crisis. Who benefits and who misfortunes depends on the detail of the contract and strategy of each actor. Till now the contract and policy issues are not unveiled.

There's backdrop in aid at AAIHDP. At the beginning of AAIHDP China had given financial aid for the construction of condominiums. Further GTZ had given technical assistance at the starting of the project. Right now international actors are working with research work only. GTZ, UN-Habitat and World Bank have been financing problem tackling researches for housing development. Currently the government confronted a financial issue. It failed to achieve housing projects on the time outline with small deviations.

AAIHDP replicated agro stone technology from China. It has advantage in time, cost and superior efficiency for partition work. The advantage of technology transfer in housing construction is basic.

The paper clearly showed that there is a loose connection among intra ministries and between the government and private (local, joint venture and foreign) investors. The government dominated housing development couldn't provide "housing for all"

The interlocking of housing development and Ethiopian economic diplomacy is the best way to adders the crisis of housing in Addis Ababa through revitalized global partnership. Attraction of FDI in the housing sector needs the revision of government decrees, policies and proclamations that can attract through incentives and protect investment with legal documents.

Addis Ababa City Administration shall focuses on how to effectively utilize resources specifically land and tax incentives to address the challenges of housing in Addis Ababa. Mass housing experience, technology and finance are expected from the private (local, joint ventures and foreign) investors. National/International Mortgage Banks are the missed actors of housing development in Addis Ababa.

\section{Conclusion and Recommendations}

\subsection{Conclusion}

Ethiopian's national interest is all about democracy and development. The strategy to realize our national interest is based on "Domestic First and External second" approach. So housing development is the subset of the nation's development. Besides housing is the imperative motor for sustainable development and poverty reduction. Addis Ababa
City Administration succeeds in the construction of colossal number of houses in Addis Ababa. It has economic, social and political impact to the recipients, contractures; MSE'S and to the entire the society.

The finding of this study uncovered that economic diplomacy is the imperative motor of integrated housing development in Addis Ababa. Ethiopian economic diplomacy has a direct impact within the quality, quantity and cost of housing provision. Ethiopian government draws in bunch of construction materials manufacturing firms based on the import substitution principles and its economic diplomacy. Addis Ababa integrated housing development has the advantage of getting the desired amount, quality and reasonable cost at a given time. The manufacturers get tremendous market that can devour colossal number of their items. In any case the firms couldn't fulfill the local demand and begin export. Till presently the housing development imports incalculable amount and number of finishing materials and others. On the other hand, there is a backdrop in technical and financial aid. The FDI directly constructing houses were small in number and focus on luxury apartments.

The major challenge of integrated housing development and real estate development in Addis Ababa exudes from the government decrees, policy and procedures that entitled the government as major actor within the housing provision. This is the orientation of the socialist ideologies. The program has intense problem of finance, mass housing experience and technology. It is exposed to high political interferences and repetitive changes. This leads to the failure of both private and government led housing development in Addis Ababa. The government utilized housing as a stick and carrot. Political affiliation has a great value than knowledge, experience and other fundamental things for the work. The private housing developers have a problem with security of tenure and focus on presale. The housing provision, administration and construction are not fair, transparent and responsible. This is against our rapid development and democratization plan.

The relationship between MOFA and MUDC is very weak. This has spillover effect in attraction of international cooperation within the housing sector and facilitation of international experience and technological know-how. The critical issues of Addis Ababa housing is related to the nations international relations. International cooperation is crucial for addressing finance and technology transfer in Addis Ababa housing.

The paper shows that post 2018 there are changes with respect to the inclusion of foreign companies in the affordable housing construction. For instance, tycoon housing developers and government begin to work cooperatively to curb the housing crisis in Addis Ababa. The Addis Ababa City Administration marked a series of memorandum of understanding and agreements. International cooperation is basic to tackle housing crisis. However, policy issues like real estate development and administration are on the draft stage. 


\subsection{Recommendations}

The approach of housing development policies shall be pragmatic not socialist, capitalist and distributive justice only. Leaving the housing sector to a particular ideology and modality has no guarantee to fulfill its objectives. Because housing development is multidisciplinary and deviates from different philosophies. All the actors should compete and contribute in quality, amount and cost. The number of houses built by the government, local and international investors shall be multiplied. Adequate and affordable houses shall be constructed for the poor, medium and high income citizens.

Addis Ababa City Administration shall curb its internal administrative issues within the housing sector. It needs strong commitment, high investment and political initiation. The decree, policies, goals and bureaucracy shall attract and protect the investment of each actor. The government shall do the following activities:

1) Facilitate infrastructure;

2) Ease of getting land;

3) Tax discount for affordable housing material supply;

4) Incentives to housing development and;

5) Building National Mortgage Housing Bank.

The research clearly proved technology transfer and financial issues couldn't be addressed by domestic capacity only. Interlocking of housing development and Ethiopian economic diplomacy is the best way to adders the crisis of housing in Addis Ababa through revitalized global partnership. The housing sector could be meaningfully changed by vigorous pursuit, attraction and promotion of the following:

1) Mega construction material manufactures;

2) Tycoon international real estate developers;

3) International suppliers;

4) Financial and technical aid;

5) Mimicking technology and technology transfer;

6) Participate in international mass housing forums.

The EIC, MOFA, MUDC and Addis Ababa City Administration shall work cooperatively to fill the crevices. A joint task force shall be initiated to curb the failure in housing development. International cooperation is critical to adders the housing crisis. The duties and responsibilities of the task force should be:

1) Facilitation of information flow;

2) Breaking bureaucratic red tapes;

3) Changing the attitude of the concerned bodies and civil servants;

4) Showing the gap of housing for local and international investors;

5) Attracting tycoon housing developers;

6) Attracting mega construction material manufacturers and/ or suppliers;

7) Soliciting financial and technical aid.

Post 2018 there are some positive changes within the attraction of international real estate developers. We shall utilize the political device for economic prosperity of the nation. Policy guides shall be prepared and endorsed by the concerned bodies. It shall be open, fair and transparent for all actors.
The recommendation for further study:

Check the role of construction material manufacturing firms, international trade, and financial and technical aid in Addis Ababa housing development in mixed or quantitative research.

\section{Acknowledgements}

Foremost, I want to offer this endeavor to Almighty God for his wisdom upon me, the strength, peace of mind and good health in order to finish this research.

I would like to express my special gratitude and thanks to my adviser, Dr. Chuol R. Kompuok for imparting his knowledge and expertise in this study.

I am highly indebted to ECSU College of Leadership and Governance School of Diplomacy \& International Relation graduate studies for their guidance and consent supervision as well as for providing the necessary information for the last three years.

I would like to express my gratitude towards my parents, Belta Lakew and Eseyneh Dagnew, for the encouragement since I was a teenager.

This thesis becomes a reality with the kind support and help of many individuals. I would like to extend my sincere thanks to all of them.

My thanks and appreciations also go to informants who willingly helped me.

\section{References}

[1] Ministry of Information of Ethiopia (2002). The Foreign Affairs and National Security Policy and Strategy of the Federal Democratic Republic of Ethiopia. Addis Ababa: Berhanena Selam Printing Enterprise.

[2] Ethiopian Investment Commission (2018). Ethiopia Investment Policies and Incentives and opportunities.

[3] UN-Habitat (2011). The Ethiopia Case of Condominium Housing: The Integrated Housing Development Programme. Nairobi. United Nations Human Settlements Programme.

[4] UN General Assembly (2015). Sustainable development goals. SDGs Transform Our World, 2030.

[5] UN-Habitat (2012). Enhancing urban safety and security. Global report on human settlements 2007. Routledge.

[6] UN Habitat, and Resiliency, B. (2008). Sustainable Cities. Vancouver.

[7] Ministry of Urban Development Housing and Construction (2014). Building 'Economically Productive, Socially Inclusive, Environmentally Sustainable, \& Well Governed' Cities. Nairobi, Kenya.

[8] Bayne, N. and Woolcock, S. (2007). The New Economic Diplomacy: Decision Making and Negotiation in International Economic Relations. $2^{\text {nd }}$ edition.

[9] Saner, R. and Yiu L. (2003). International Economic Diplomacy: Mutations in postmodern times. Netherlands Institute of International Relations. ISSN 1569-2981. 
[10] Van Bergeijk, A. G., Heijmans, M. O. and Melissen J. (2011). Economic diplomacy: economic and political perspectives. Martinus Nijhoff Publishers. ISBN 978-90-04-20960-2.

[11] Ministry of Foreign Affairs of Ethiopia (2016). The Econometrics of diplomacy Ethiopian foreign policy. Yohannes Gebeyehu.

[12] Aberg, J. H. and Becker, D. (2021). The world is more than a stage: foreign policy, development and spatial performativity in Ethiopia. Territory, Politics, Governance.

[13] Leulseged, T. (2012). Commercial Diplomacy of Ethiopia.

[14] Hohmann, J. (2013). The right to housing: Law, concepts, possibilities. Bloomsbury.

[15] Hegedus, J., \& Teller, N. (2006). Managing risks in the new housing regimes of the transition countries - the case of Hungary. Amsterdam: IOS Press.

[16] Gao, L. (2010). Achievements and Challenges: 30 Years of Housing Reforms in the People's Republic of China. Asian Development Bank.

[17] Investopedia (June 4, 2021). Neoclassical Economics. By: Will Kenton. [Online] https://www.investopedia.com Accessed on: July 10, 2021.

[18] Clapham, D. (2018). Housing theory, housing research and housing policy. Housing, Theory and Society, 35 (2). pp. $163-$ 177. ISSN $1403-6096$ doi: https://doi.org/10.1080/14036096.2017.1366937

[19] Jaffe, A. J. (1989). Concepts of property, theories of housing, and the choice of housing policy. The Netherlands journal of housing and environmental research.

[20] UN-Habitat (2015). Housing at the Center of the New Urban Agenda. Nairobi, Kenya.

[21] UN-Habitat (2015). Habitat iii issue paper 22-informal settlements. New York: UN Habitat.

[22] Wetzstein, S. (2017). The global urban housing affordability crisis. Urban Studies.

[23] Kissick, D., Leibson, D., Kogul, M., Bachmann, J., Anderson, J. and Eckert, J. (2006). Housing for all: essential to economic, social, and civic development. Prepared for the World Urban Forum III.

[24] Ronald R. (2008). Between investment, asset and use consumption: The meanings of homeownership in Japan. Housing Studies.
[25] Semonun Addis Visits. (Sep 1, 2018) Tsehaye Real Estate Part 1. Ebs Tv World Wide. [Online] https:// www.youtube.com Accessed on: April 13, 2021.

[26] Ethiopian Herald (April 7, 2020). Economic diplomacy witness huge gulf investment. Araya.

[27] Ministry of Foreign Affairs (2019). Business Diplomacy Update. 10th special edition.

[28] Addis Tube (May 20, 2021). Deputy Mayor of Addis Ababa signed a memorandum of understanding with UAE housing developers on social media. [Online] https:// www.youtube.com Accessed on: May 20, 2021.

[29] Fana Broadcasting Corporate (June 2, 2021). Memorandum of Understanding between Deputy Mayor of Addis Ababa and Property 2,000 South African Company. [Online] https:// www.youtube.com Accessed on: June 02, 2021.

[30] World Highways (2018). Ethiopia's challenging cement market: consumption stimulation. [Online] htpps://www.worldhigways.com. Accessed on: Jun 3, 2021.

[31] Derba Midroc Cement (2021). Cementing the Nations Development. [Online] www.derbacement.com Accessed on: Jun 3, 2021.

[32] Ethio Cement (2021). Company Profile. [Online] www.ethiocement.com Accessed on: Jun 3, 2021.

[33] Cement News (2021). Ethiopia's cement sector is on the brink of transition. [Online] https://www.cement.com. Posted on: Mar 12, 2021 Accessed on: Jun 3, 2021.

[34] CGTN (Aug 31, 2016. Ethiopia's Real Estate grows as investors pour funds in to the sector. https:// www.youtube.com Accessed on: April 13, 2021.

[35] ETV (Aug 12, 2020). Challenges of Real Estate Developers in Ethiopia. By: Daniel Haile [Online] https:// www.youtube.com Accessed on: April 13, 2021.

[36] Arts TV (May 15, 2021). Metropolitan Real Estate Ethiopia. [Online] https:// www.youtube.com Accessed on: May 15, 2021.

[37] Birhanu, P. (2011). Study on private residential real estate development in Addis Ababa. Addis Ababa Institute of Technology, Addis Ababa.

[38] Ministry of Urban Development and Construction (2012). Construction Industry Policy. 